\title{
Public Affairs Plan
}

\section{September 1995}

\section{DISCLAIMER}

This report was prepared as an account of work sponsored by an agency of the United States Government. Neither the United States Government nor any agency thereof, nor any of their employees, makes any warranty, express or implied, or assumes any legal liability or responsibility for the accuracy, completeness, or usefulness of any information, apparatus, product, or process disclosed, or represents that its use would not infringe privately owned rights. Reference herein to any specific commercial product, process, or service by trade name, trademark, manufacturer, or otherwise does not necessarily constitute or imply its endorsement, recommendation, or favoring by the United States Government or any agency thereof. The views and opinions of authors expressed herein do not necessarily state or reflect those of the United States Government or any agency thereof. 


\section{INTENDED FOR PUBLIC RELEASE}

This report has been reproduced from the best available copy. Available in paper copy and microfiche

Number of pages in this report: 29

DOE and DOE contractors can obtain copies of this report from:

Office of Scientific and Technical Information

P.O. Box 62

Oak Ridge, TN 37831

(615) 576-8401

This report is publicly available from:

National Technical Information Service

Department of Commerce

5285 Port Royal Road

Springfield, VA 22161

(703) 487-4650 


\section{DISCLAIMER}

Portions of this document may be illegible in electronic image products. Images are produced from the best available original document. 
REV. 0

\section{PUBLIC AFFAIRS PLAN}

\section{September 1995}

Prepared for

U.S. Department of Energy

Environmental Restoration Division

UMTRA Project Team

Albuquerque, New Mexico

Prepared by

Jacobs Engineering Group Inc.

Albuquerque, New Mexico 


\section{TABLE OF CONTENTS}

Section

Page

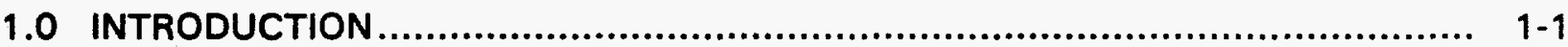

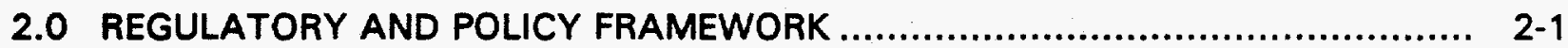

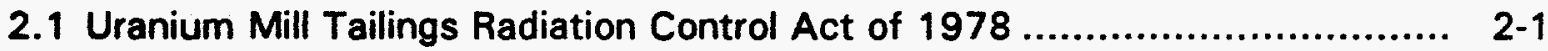

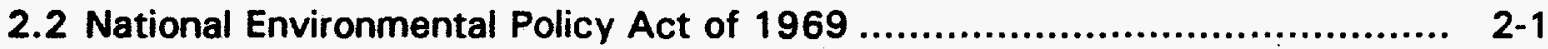

2.3 Secretary of energy public participation policy................................... $2-1$

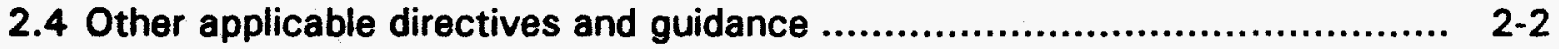

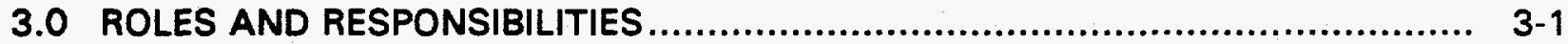

3.1 DOE Albuquerque Operations Office, Environmental Restoration Division.... 3-1

3.2 DOE Grand Junction Projects Office ............................................. $3-1$

3.3 DOE Albuquerque Operations Office, Office of Public Affairs ................... 3-1

3.4 UMTRA Project TAC............................................................. $3-1$

3.5 UMTRA Project remedial action contractor.................................... $3-2$

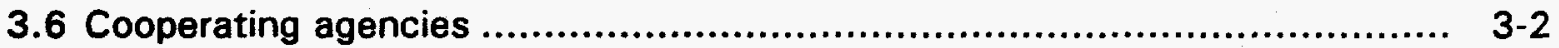

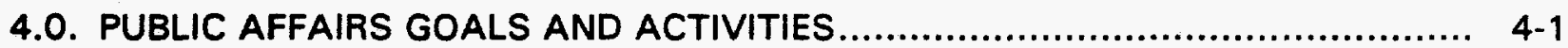

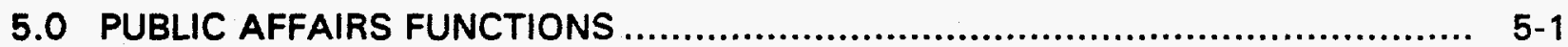

5.1 Media relations ..................................................................... $5-1$

5.2 Internal information ............................................................... $5-1$

5.3 Public participation ................................................................. $5-1$

5.4 Community relations............................................................... $5-2$

5.5 Intergovernmental relations ...................................................... $5-3$

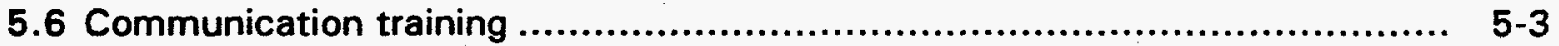

5.7 Emergency communication...................................................... 5

6.0 HOW PUBLIC AFFAIRS EFFECTIVENESS WILL BE EVALUATED ................... $6-1$

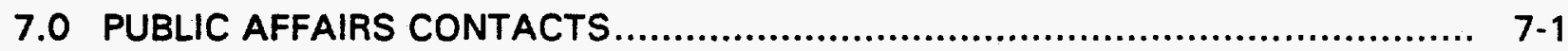

8.0 LIST OF CONTRIBUTORS......................................................... 8 -1

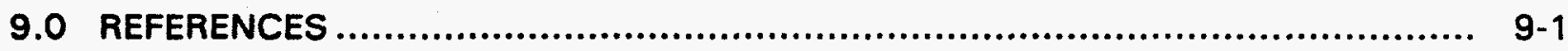




\section{LIST OF ACRONYMS}

$\begin{array}{ll}\text { Acronym } & \text { Definition } \\ \text { DOE } & \text { U.S. Department of Energy } \\ \text { ERD } & \text { Environmental Restoration Division } \\ \text { FY } & \text { fiscal year } \\ \text { GJPO } & \text { Grand Junction Projects Office } \\ \text { NEPA } & \text { National Environmental Policy Act } \\ \text { OPA } & \text { Office of Public Affairs } \\ \text { ORPS } & \text { Occurrence Reporting and Processing System } \\ \text { RAC } & \text { Remedial Action Contractor } \\ \text { TAC } & \text { Technical Assistance Contractor } \\ \text { UMTRA } & \text { Uranium Mill Tailings Remedial Action } \\ \text { UMTRCA } & \text { Uranium Mill Tailings Radiation Control Act }\end{array}$




\subsection{INTRODUCTION}

The purpose of the Uranium Mill Tailings Remedial Action (UMTRA) Project Public Affairs Plan is to establish goals for the fiscal year (FY) 1996 UMTRA Project public affairs program and to identify specific activities to be conducted during the year. It describes the roles of various agencies involved in the public affairs program and defines the functions of the UMTRA Project Technical Assistance Contractor (TAC) Public Affairs Department. It replaces the FY 1995 Public Affairs Plan (DOE/AL/62350-154). The plan also describes the U.S. Department of Energy's (DOE) plans to

- keep stakeholders and other members of the public informed about UMTRA Project policies, plans, and activities, and

- provide opportunities for stakeholders and interested segments of the public to participate in UMTRA Project decision-making processes.

The plan applies to the UMTRA Project Team; the DOE Grand Junction Projects Office (GJPO); the DOE Albuquerque Operations Office, Office of Public Affairs (OPA); the TAC; the UMTRA Project Remedial Action Contractor (RAC); and other cooperating agencies. 


\subsection{REGULATORY AND POLICY FRAMEWORK}

\subsection{URANIUM MILL TAILINGS RADIATION CONTROL ACT OF 1978}

The UMTRA Project was authorized by Congress in the Uranium Mill Tailings Radiation Control Act (UMTRCA) of 1978, (42 USC $\$ 7901$ et seq.), as amended. The UMTRCA provides for a cooperative effort between DOE and affected states and Indian tribes for the cleanup of designated abandoned or inactive uranium mill tailings sites and vicinity properties located in 10 states, 9 of which are west of the Mississippi River. The UMTRCA was amended in 1983 to include vicinity properties contaminated with residual radioactive material in Edgemont, South Dakota. It was amended again in 1988 and 1992 to extend the time for project completion and to provide for restoration of ground water contamination caused by uranium processing at UMTRA Project sites.

Section 111 of the UMTRCA states:

In carrying out the provisions of this title, including the designation of processing sites, establishing priorities for such sites, the selection of remedial actions, and the execution of cooperative agreements, the Secretary lof Energy], the Administrator lof the Environmental Protection Agency], and the [Nuclear Regulatory] Commission shall encourage public participation and, where appropriate, the Secretary shall hold public hearings relative to such matters in the States where processing sites and disposal sites are located.

\subsection{NATIONAL ENVIRONMENTAL POLICY ACT OF 1969}

National Environmental Policy Act (NEPA) requires an evaluation of the environmental impact of major federal actions that may significantly affect the environment. Public participation is an important part of the process. A number of formal provisions exist for participation by all interested parties, including other federal agencies, state and local agencies, American Indian tribes, and the general public (including proponents and opponents of an action). These public participation requirements are detailed in the Council on Environmental Quality regulations (40 CFR 1500-1508) for implementing provisions of the NEPA and in the DOE implementing procedures for NEPA (10 CFR 1021).

\subsection{SECRETARY OF ENERGY PUBLIC PARTICIPATION POLICY}

The Secretary of Energy, in a policy issued in July 1994, sends a very clear message:

Department officials will engage in an open and on-going communication process and consistently listen and respond to 
suggestions made by the public. The Department will incorporate public input into its decisions where appropriate and feasible and will provide feedback to the public on its reasoning.

The full text of the Secretary's policy can be found in the Secretary of Energy's memorandum, Guidance on Implementation of the Department's Public Participation Policy, 29 July 1994, attached to this plan.

\subsection{OTHER APPLICABLE DIRECTIVES AND GUIDANCE}

UMTRA Project public affairs activities are also conducted in compliance with the following orders and guidance documents:

- DOE Order 1220.1A, Congressional and Intergovernmental Affairs, 1992.

- DOE Order 1230.2, American Indian Tribal Government Policy, 1992.

- DOE Order 1240.2B, Unclassified Visits and Assignments by Foreign Nationals, 1992.

- DOE Order 1340.1B, Management of Public Communication Publications and Scientific, Technical, and Engineering Publications, 1993.

- DOE Order 1350.1, Audiovisual and Exhibits Management, 1981.

- DOE Order 1430.1D, Scientific and Technical Information Management, 1994.

- DOE Order 1700.1, Freedom of Information Program, 1979.

- DOE Order 1800.1A, Privacy Act, 1984.

- DOE Order 5000.3B, Occurrence Reporting and Processing of Operational Information, 1993.

- DOE Order 5400.1, General Environmental Protection Program, 1988.

- DOE Order 5440.1E, National Environmental Policy Act Compliance Program, 1992.

- DOE Order 5500.4A, Public Affairs Policy and Planning Requirements for Emergencies, 1992.

- DOE Order 5500.5A, Public Affairs Policy and Planning Requirements for a Fuel Supply Disruption Emergency, 1992. 
- Public Participation Policy for Environmental Restoration and Waste Management, DOE Office of Environmental Restoration and Waste Management, 1992.

- Public Participation Guidance for Environmental Restoration and Waste Management, DOE Office of Environmental Restoration and Waste Management, 1993.

- Effective Public Participation Under the National Environmental Policy Act, Office of NEPA Policy and Assistance, U.S. Department of Energy, December 1994. 


\subsection{ROLES AND RESPONSIBILITIES}

3.1 DOE ALBUQUERQUE OPERATIONS OFFICE, ENVIRONMENTAL RESTORATION DIVISION

Environmental Restoration Division (ERD) has day-to-day management responsibility for public information and public participation for the surface phase of the UMTRA Project. ERD directs the activities of the TAC in preparing information materials and events, planning public participation, and carrying out public affairs activities. ERD's UMTRA Project Team personnel serve as principal spokespersons for the surface phase of the UMTRA Project in public meetings and interviews with the news media.

\subsection{DOE GRAND JUNCTION PROJECTS OFFICE}

GJPO has day-to-day management responsibility for public information and public participation for the ground water phase of the UMTRA Project. GJPO directs the activities of the TAC in preparing information materials and events, planning public participation, and carrying out public affairs activities. GJPO personnel are the principal spokespersons for the ground water phase of the UMTRA Project in public meetings and interviews with the news media.

\subsection{DOE ALBUQUERQUE OPERATIONS OFFICE, OFFICE OF PUBLIC AFFAIRS}

OPA, with guidance and oversight from ERD and GJPO, acts as the prime contact within the DOE on all public information and public participation activities. OPA coordinates and approves all UMTRA Project-related public information and public participation programs.

\section{$3.4 \quad$ UMTRA PROJECT TAC}

The TAC, through its Public Affairs Department, identifies the need for, and proposes the scope and content of, public information materials and activities. The TAC also identifies stakeholders with an interest in the UMTRA Project, develops appropriate plans to establish and maintain two-way communication, supports ERD and GJPO in the implementation of the plan, trains or arranges training for UMTRA Project spokespersons, and evaluates the success of communication programs. Upon approval by OPA these activities are performed under the direction of both ERD and GJPO.

In addition, ERD, GJPO, or OPA may request TAC assistance in the preparation, reproduction, and distribution of public information materials; the planning and coordination of special events and workshops for sharing technology; the development and updating of UMTRA Project briefing books; the development of testimony, presentations, and special reports; the development of information and media packets; the development and production of video tapes and other audio-visual materials; and the development and maintenance of outreach lists 
of government officials, media representatives, special interest groups, and community leaders.

The Public Affairs Department plans and conducts programs to maintain awareness of UMTRA Project-related issues of concern to stakeholders and brings those issues to the attention of UMTRA Project management. The Department plans and supports the implementation of public participation activities including community advisory groups, public meetings, public hearings, meetings with local governmental bodies and informal small groups, and individual communication with stakeholders.

The Public Affairs Department works closely with the TAC Site Management, Technical Services, and Integrated Project Management Systems departments to prepare public information materials and plans for public involvement activities. It coordinates public affairs activities and products which pertain to the surface and ground water phases of the UMTRA Project with both ERD and GJPO.

\subsection{UMTRA PROJECT REMEDIAL ACTION CONTRACTOR}

The RAC, in coordination with the TAC Public Affairs Department, ERD, GJPO, and OPA, provides support for public information and public participation activities as requested. The RAC will refer news media inquiries regarding site construction activities to the TAC Public Affairs Department.

\subsection{COOPERATING AGENCIES}

Public involvement activities for UMTRA Project sites will be coordinated with the appropriate state or tribal cooperating agency. Special events will be coordinated with the appropriate state, federal or tribal cooperating agencies. 


\subsection{PUBLIC AFFAIRS GOALS AND ACTIVITIES}

UMTRA Project public affairs goals for FY 1996 include the following:

- Continue to keep the public informed about the UMTRA Project through the prompt release of accurate information to the news media.

- Increase public awareness of UMTRA Project accomplishments by broadening the distribution of news releases to include more DOE and industry publications.

- Increase public awareness of the success of the UMTRA Project Cost Reduction/ Productivity Improvement Program.

- Raise the level of public understanding of DOE's ability to conduct remediation activities in an environmentally sound and safe manner while minimizing risks to the environment, workers, and the general public.

- Increase informed public involvement in, and support for, DOE's environmental restoration mission by expanding the opportunities for stakeholder participation in the Department's decision-making process.

- Place greater emphasis upon providing support to schools in communities near UMTRA Project sites; provide speakers, displays, written information, surplus DOE equipment, etc., to students interested in the environment.

- Maintain the framework for two-way communication about the ground water Programmatic Environmental Impact Statement with key audiences at UMTRA Project site communities.

- Further refine the format and appearance of the annual status report of the UMTRA Project for distribution to news media representatives, federal, state, local, and tribal officials, civic leaders, and other interested stakeholders.

- Continue conducting in-house communication training to ensure the UMTRA Project spokespersons are better prepared to communicate effectively during public meetings and news media interviews; ensure that all new managers and technical staff members are given basic training on procedures and policies related to contact with the news media and general public.

- Further improve the content of the UMTRA Update internal newsletter by expanding coverage to include the accomplishments of UMTRA Project people assigned to GJPO.

- Establish and maintain an UMTRA World Wide Web home page site, making UMTRA information available through Internet. 
- Develop and publish a two-fold brochure about the UMTRA Project that can be used as a give-away at symposia, public events, and other occasions where the UMTRA Project display is exhibited.

- Refine and modernize the design and appearance of the UMTRA Update internal newsletter.

The following UMTRA Project public affairs activities for FY 1996 will be carried out in support of major UMTRA Project events and activities:

- Develop plans and strategies to communicate to the public details about the transfer of the ground water phase of the UMTRA Project to GJPO.

- Recognize completion of surface remedial action and cell closure at Gunnison and Rifle, Colorado, with appropriate closing ceremonies.

- Maintain effective two-way communication with stakeholders in the Naturita, Nucla, and Norwood communities and monitor emerging issues that might impact the removal of tailings from the Naturita, Colorado, site.

- Maintain effective two-way communication with stakeholders in the Maybell and Slick Rock, Colorado, communities as remedial action continues at these sites.

- Prepare and distribute news releases to announce licensing of the Tuba City, Arizona; Durango, Colorado; and Shiprock, New Mexico, sites as well as any other sites for which licensure is completed during the fiscal year.

- Conduct public meetings to communicate results of baseline risk assessments in appropriate site communities as they become available.

- Conduct an annual UMTRA States and Tribes Coordinating Meeting to provide opportunities for dialog with federal, regional, state, and tribal cooperating agencies.

- Continue the Indian Outreach Program to improve two-way communication between American Indian Tribes and UMTRA Project people, and develop a basis for better understanding of tribal cultural sensitivities and needs.

- Monitor the status of Belfield and Bowman, North Dakota, the two UMTRA Project sites yet to be started, and inform stakeholders about any decisions which impact those sites.

- Publicize the scope and extent of new field activities at the Tuba City site. 


\subsection{PUBLIC AFFAIRS FUNCTIONS}

\subsection{MEDIA RELATIONS}

Media relations activities are designed to provide all news media (national, state, and local) with timely and accurate information about UMTRA Project activities, events, and status changes. These activities include, but are not limited to, news releases, fact sheets, interviews, response to news media queries, media briefings, UMTRA Project media kits, public service announcements, and visual materials for television. Managers and technical staff from ERD, GJPO, or contractor organizations should complete spokesperson training before undertaking substantive roles in media interviews. The TAC Public Affairs Department will provide support in preparation for media interviews.

News releases and other written material intended for release through the news media will be prepared by the TAC Public Affairs Department in coordination with TAC site management, technical staff, ERD, and GJPO as appropriate. Materials will be reviewed and approved by OPA and, when appropriate, by the DOE Office of Congressional, Public, and Intergovernmental Affairs, through OPA. Once approved, materials will be produced and distributed by the TAC Public Affairs Department.

\subsection{INTERNAL INFORMATION}

Because internal staff members are significant stakeholders in the UMTRA Project and because an informed staff is vital to maintaining accurate communication with external publics, the UMTRA Project conducts an internal information program through a newsletter and through an electronic communication effort on the UMTRA Project Local Area Network dubbed News Flash. The UMTRA Update is a monthly internal newsletter published to keep the diverse members of the UMTRA Project team informed of UMTRA Project activities and events. The newsletter is distributed by the TAC Public Affairs Department to ERD; GJPO; TAC; RAC; and federal, state, and tribal cooperating agencies. Late-breaking UMTRA Project news may also be disseminated electronically via the News Flash bulletin board.

\subsection{PUBLIC PARTICIPATION}

The UMTRA Project makes an ongoing effort to keep stakeholders in site communities and nationwide informed of UMTRA Project plans and activities, and to involve them in key aspects of the decision-making process. In keeping with the Secretary of Energy's policy, the activities of the UMTRA Project must be open to the full view and input of those whom it serves, consistent with applicable laws, regulations, and contracts.

Citizens have a right to know about proposed government actions and to be heard in the planning of activities that influence their lives. The DOE must 
comply with the legal requirements for public participation and will establish processes that are responsive to the interests and concerns of those who live in the affected communities. The DOE will also encourage state, tribal, and local governments, as well as individuals, to join actively in the decision-making process. This will ensure that the resulting decisions are made with the full knowledge of the public's views and that these decisions address the public's concerns to the extent possible within the law.

The target audience for these efforts consists of:

- legislators (federal, state, and tribal);

- executive branch officials (federal, state, tribal, and local);

- officials of special interest groups;

- leaders of the business and professional community;

- news media professionals;

- residents in the vicinity of abandoned mill sites and proposed or selected disposal sites;

- public opinion leaders;

- the academic community; and

- $\quad$ other interested stakeholders.

\subsection{COMMUNITY RELATIONS}

The UMTRA Project is committed to maintaining good relations and open channels of communication with the people in the communities surrounding the sites. The UMTRA Project recognizes the need for honesty and forthrightness. Consistent, credible, and quality performance factors are the elements upon which to build public understanding and trust. The TAC Public Affairs Department will support the community relations effort by:

- conducting educational presentations in schools and before community groups by UMTRA Project technical staff;

- $\quad$ supporting to citizen advisory groups in site communities;

- conducting public meetings and public hearings;

- providing toll-free telephone lines (1-800-523-6495; in New Mexico, 1-800-423-2539); 
- providing responses to requests for information;

- conducting site tours;

- providing UMTRA Project annual status reports;

- providing annual UMTRA Project videos;

- providing other selected video products as appropriate;

- video-teleconferencing through the Waste-Management Education and Research Consortium; and

- conducting special events to recognize the achievement of UMTRA Project milestones.

\subsection{INTERGOVERNMENTAL RELATIONS}

The UMTRA Project provides briefings to the staff of U.S. Congressional offices, state legislators, tribal legislative bodies, and local governments. Congressional briefings are generally at the request of the Congressional office and are coordinated through OPA and the DOE Office of Congressional, Public, and Intergovernmental Affairs. As appropriate, the UMTRA Project also provides written responses, through channels, to inquiries from the legislative or executive branches of federal, state, tribal, and local governments.

\subsection{COMMUNICATION TRAINING}

The TAC Public Affairs Department provides training in presentation skills, handling news media interviews, risk communication, public meeting management, and other public communication topics for UMTRA Project management and technical staff. Training is supported with individual coaching for specific communication events.

\subsection{EMERGENCY COMMUNICATION}

The UMTRA Project Occurrence Reporting and Processing System (ORPS) includes notification of TAC Public Affairs Department staff in event of an emergency. Information received from ORPS is used to prepare statements or news releases, as appropriate, to respond to potential inquiries from the news media. Public communication relating to accidents or other emergencies is coordinated through ERD, GJPO, and OPA. 


\subsection{HOW PUBLIC AFFAIRS EFFECTIVENESS WILL BE EVALUATED}

The effectiveness of the UMTRA Project public affairs program will be assessed annually, and these assessments will include the views and recommendations of stakeholders.

Following the completion of special events and other public affairs initiatives, the UMTRA Project Team and GJPO will evaluate the effectiveness of public communication activities by using:

- Evaluation forms distributed during meetings and event.

- Informal personal interviews of people attending meeting and events.

- Comments received in letters from government agencies, civic organizations, and members of the general public.

- Comments received over the toll-free telephone lines established to provide a 24-hour forum for customer feedback.

ERD and GJPO will establish the criteria by which the public affairs effectiveness will be judged. The TAC Public Affairs Department will evaluate these assessments and recommend changes, as needed, to improve the effectiveness of the UMTRA Project's public affairs effort. 


\subsection{PUBLIC AFFAIRS CONTACTS}

\section{Gaeton Falance}

Technical Support Specialist

Management Services Team

Environmental Restoration Division

U.S. Department of Energy

Albuquerque Operations Office

P.O. Box 5400

Albuquerque, NM 87185

(505) 845-5636

\section{Audrey Berry}

Public Information Officer

DOE Grand Junction Projects Office

P.O. Box 2567

Grand Junction, CO 81502

(970) 248-7727

Bernard R. Pleau, Jr.

Public Affairs Specialist

Office of Public Affairs

Albuquerque Operations Office

U.S. Department of Energy

P.O. Box 5400

Albuquerque, NM 871785-5400

(505) 845-5951

Frederick W. Morgan, APR

Manager, Public Affairs

Public Affairs Department

Jacobs Engineering Group Inc.

2155 Louisiana Blvd. NE

Suite 10,000

Albuquerque, NM 87110

(505) 880-2516 


\subsection{LIST OF CONTRIBUTORS}

The following individuals contributed to the preparation of this report.

\begin{tabular}{ll}
\hline Name & Contribution \\
\hline S. Giammo & Overall document responsibility; authorship \\
D. Bierley, M. Miller, F. Morgan & Document review \\
L. Sanchez & Text processing \\
D. Tamez & Technical Editing \\
\hline
\end{tabular}




\subsection{REFERENCES}

\section{CODE OF FEDERAL REGULATIONS}

10 CFR Part 1021. National Environmental Policy Act; Implementing Procedures and Guidelines Revocation; Final Rule and Notice, U.S. Department of Energy.

10 CFR Part 1500-1508. Regulations for Implementing the Procedural Provisions of the National Environmental Policy Act, Council on Environmental Quality.

\section{UNITED STATES CODE}

42 USC $\$ 7901$ et seq., Uranium Mill Tailings Radiation Control Act, November 8, 1978. 


\section{ATTACHMENT}

Secretary of Energy Memorandum, July 29, 1994, Guidance on Implementation of the Department's

Public Participation Policy 


\section{The Secretary of Energy \\ Washington, DC 20585}

July 29,1994

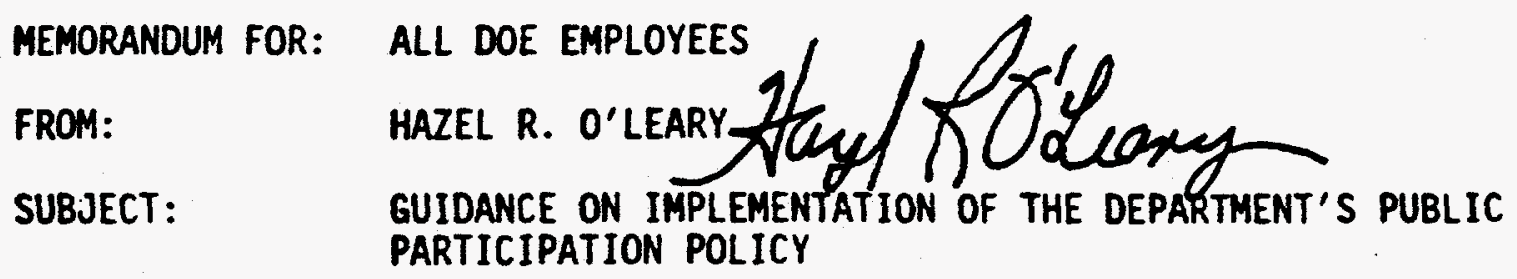

Public participation must be a fundamental component of the Department's program operations, planning activities, and decision-making. The business of the Department must be open to the full view and input of those whom it serves, consistent with applicable laws, regulations, and contracts.

To ensure that we operate in this manner, the Department's Public Participation Policy was developed by a cross-cutting team that included field representatives. This policy marks a clear break with past practice by challenging the Department and its contractors to perform to a new standard of openness and service.

Within this policy framework, each site will develop its own public participation program and plans in consultation with stakeholders and with the concurrence of appropriate Headquarters program offices. In achieving the goals of public participation, managers are responsible for:

* identifying, planning, funding, supporting, and implementing the appropriate level and scope of public participation activities in their programs;

* ensuring that public participation principles, values, and processes are fully understood and practiced within their programs and at their sites;

* providing necessary human, information, systems, and financial resources; and,

* ensuring that their staff receive basic communicátion and public participation training, and where appropriate, advanced public participation training.

To promote teamwork, share the benefits of experience and innovation at individual sites, and avoid unreasonable demands on site personnel or stakeholders, program and staff offices will coordinate public participation activities through the Office of Public and Consumer Affairs at Headquarters or with its counterpart in the field. This coordination in no way limits or dilutes field managers' authority to implement effective public participation programs or program managers' responsibility to plan, fund, and support appropriate levels of public participation in their programs. 
The effectiveness with which each site/program implements the Department's Public Participation Policy will be assessed annually, and these assessments must include the views and recommendations of stakeholders. Stakeholders will also be invited to participate in the processes used to develop criteria and measures for judging effectiveness. The Director of Public and Consumer Affairs will evaluate these annual assessments and recommend changes to improve the effectiveness of the Department's public participation efforts.

While public participation processes must be tailored to meet specific site, program, and stakeholder needs, the following broad guidance provides a framework to assist management in implementing this policy Department-wide. Using the following critical policy elements and implementing actions as a guide, Headquarters and Field Elements should consult with stakeholders to develop appropriate public participation programs and activities.

\section{CRITICAL POLICY ELEMENTS:}

I. The Department recognizes that honesty and forthrightness in dealing with stakeholders, and consistent, credible, quality performance are the bases upon which to build publjc understanding and trust.

Implementing Actions:

* Department officials will be open, honest, and accurate in their public statements and accountable for diligent follow-up and timely results from the commitments they make.

* Department officials will engage in an open and on-going communication process and consistently listen and respond to suggestions made by the public. The Department will incorporate public input into its decisions where appropriate and feasible and will provide feedback to the public on its reasoning.

* Department officials will recognize and reward leadership and results in the area of public participation.

II. Departmental program development, planning, and decision-making processes will be clearly defined, with regular, easily identified access points for public input.

Implementing actions:

* Senior management will ensure that Department personnel, other Federal, State, and local officials, Tribes, and other stakehoiders are appropriately integrated into their planning activities and decision-making processes.

* Stakeholders and field managers will determine and identify pre-decisional access points for public input. 
III. Headquarters, field offices, laboratories, and facilities will operate as an integrated team in planning local and national public participation programs by combining resources, sharing information, and coordinating activities.

\section{Implementing actions:}

* Headquarters Elements will coordinate their planning of public participation activities with the Office of Public and Consumer Affairs and with affected sites, including the site Public Affairs/External Relations director.

* Field managers, as those closest to affected communities and stakeholders, will facilitate accommodation between local and national interests.

IV. The Department will establish and support training and education programs to meet evolving public participation needs, both internally and externally.

\section{Implementing actions:}

* Senior management, at Headquarters and in the field, will identify and coordinate communication and public participation training on a priority basis until all appropriate headquarters and site personnel are trained.

* In consultation with stakeholders, field managers will make recommendations on the timing and content of needed external education/training programs.

V. The Department will foster candid information exchanges and ongoing two-way communication using a variety of mediums.

\section{Implementing actions:}

* Whether formal or informal, all public participation activities will be conducted in a spirit of openness, respect for different perspectives, and a genuine quest for a diversity of information and ideas.

* The Department will work to establish, announce, and manage topical data bases of reliable, timely information available to the public through telephone and computer access. 


\section{PUBLIC PARTICIPATION POLICY}

PUBLIC

PARTICIPATION:

POLICY:

PURPOSE :
Public participation is open, ongoing, two-way communication, both formal and informal, between the Department of Energy and its stakeholders. This steady, interactive communication enables each party to learn about and better understand the views and positions of the other. The Department recognizes the many benefits to be derived from public participation, for both stakeholders and DOE. Public participation provides a means for the Department to gather the most diverse collection of opinions, perspectives, and values from the broadest spectrum of the public, enabling the Department to make better, more informed decisions. Public participation benefits stakeholders by creating an opportunity to provide input and influence decisions.

Public participation is a fundamental component in program operations, planning activities, and decision-making within the Department. The public is entitled to play a role in Departmental decision-making.

This policy is intended to ensure that public participation is an integral and effective part of Departmental activities and that decisions are made with the benefit of important public perspectives. This policy provides a mechanism for bringing a broad range of diverse stakeholder viewpoints and values early into the Department's decision-making processes. This early involvement enables the Department to make more informed decisions, improve quality through collaborative efforts, and build mutual understanding and trust between the Department and the public it serves.

This policy is designed to function as a general framework within which all Department programs sháll operate. While it applies to all levels of DOE, its intent is development and implementation of effective public participation programs at each site. In conjunction with its stakeholders and field manager, each site shall develop and implement a public participation program that promotes openness and two-way communication and is tailored to meet specific program, site, and stakeholder needs. This policy is not intended to affect legal requirements imposed by law, regulation, or contractual agreement; neither does it modify any legal rights available to the public under current law. 
DEFINITION: Under this policy, the Department actively seeks, considers, and incorporates or otherwise responds in a timely manner to the views of its stakeholders, thereby providing them an opportunity to influence decisions. Stakeholders are defined as those individuals and groups in the public and private sectors who are interested in and/or affected by the Department's activities and decisions. Public participation is defined as open, ongoing two-way communication, both formal and informal, within the DOE Complex and between the Department and its stakeholders. This cormunication will vary widely in nature and scope and may include, but is not limited to, informal conversations, scheduled meetings and workshops, legally required hearings, and Federal-Statelocal-Tribal agreements.

GOALS: The goals of the Department's Public Participation Policy are:

1. The Department actively seeks and considers public input, and incorporates or otherwise responds to the views of its stakeholders in making its decisions.

II. The public is informed in a timely manner about and empowered to participate in the Department's decision-making processes, which are open, understandable, and consistently followed. Access points for public input are clearly defined from the earliest stages of a decision process and provide adequate time for stakeholders to participate.

III. Credible, effective public participation processes are consistently incorporated into the Department's program operations, planning activities, and decision-making processes, at headquarters and in the field. Every employee within the DOE Complex shares responsibility to promote, practice, and improve public participation.

CORE VALUES: Though program-specific public participation activities may vary throughout the DOE Complex, each program will be characterized by the following core values:

Accessibility: Known avenues to Department leaders who are available, approachable, and open to the public.

Accountability: Responsibility to the public for its decisions and a willingness to provide explanations for the rationales behind its decisions.

Accuracy: Commitment to the truth.

Communication: Open, two-way exchange of information, knowledge, and perspectives between the Department and its stakeholders. 
Consistency: Stakeholder interactions marked by regularity and continuity.

Fairness: objectivity and freedom from favor toward any side.

Honesty:

Commitment to fairness, trustworthiness, and straightforwardness.

Innovation: Introduction of new ideas, methods, and approaches.

Doenness:

Ready accessibility and a willingness to listen to, consider, and respond to stakehoiders.

Peer review: Reexamination - of key issues and decisions by internal and external peers.

Respect: Consideration and deference in the treatment of stakeholders.

Responsiveness: Timely and empathetic consideration of and response to the needs, wants, and concerns of stakeholders.

Scientific Credibility: Commitment to the pursuit of sound, dependable, leading edge science.

Sincerity: Openness, frankness, and truthfuiness in all stakeholder communications.

Time/Timeliness: Adequate amount of time for stakeholders to participate in Department decision-making processes. Timely responses to stakeholder input and requests.

Timely Departmental decision-making processes supported but not hindered or delayed by public participation.

ACCOUNTABILITY: Senior departmental, program, and field managers are accountable for assuring that public participation activities meet the goals of this policy and the needs of stakeholders; are fully coordinated; and reflect Departmental principles and values. Managers are responsible for implementing plans that assure that public participation needs for their programs or projects are identified and satisfied in the decision-making process. Public Participation is a performance element for these managers. 